Kallmann syndrome with characteristic magnetic.... Sri Lanka Journal of Child Health, 2016; 45(4): 288-290

Picture Stories

\title{
Kallmann syndrome with characteristic magnetic resonance imaging findings
}

\author{
*Kakali Roy ${ }^{1}$, Dipankar Das ${ }^{1}$ \\ Sri Lanka Journal of Child Health, 2016; 45(4): 288-290 \\ DOI: http://dx.doi.org/10.4038/sljch.v45i4.8038
}

(Key words: Kallmann syndrome, MRI findings)

\begin{abstract}
Introduction
Kallmann syndrome (KS) is a neuronal migration disorder characterised by hypogonadotropic hypogonadism associated with anosmia or hyposmia. It affects males more than females with a male to female ratio of around $6: 1^{1}$. We report a rare case of Kallmann syndrome with delayed puberty, anosmia and characteristic magnetic resonance imaging (MRI) findings.
\end{abstract}

\section{Case report}

A 14 year old boy of normal intelligence presented with delayed puberty and anosmia since childhood without a similar history in the family. Physical examination revealed a height of $154.5 \mathrm{~cm}$ (more than 10th centile), arm span of $159 \mathrm{~cm}$ and a stretched penile length (SPL) of $3.5 \mathrm{~cm}$. Bilateral testicular volume was pre-pubertal around $2 \mathrm{cc}$. (Puberty-4 cc, adult-12.5 to $19 \mathrm{cc}$ ) with sparse pubic hair (Tanner's staging G1P2) ${ }^{2}$. Hormonal work up revealed inappropriately low luteinising hormone (LH) $0.07 \mathrm{mIU} / \mathrm{ml}$ (Male: 1.5-9.3) and folliclestimulating hormone (FSH) $1.05 \mathrm{mIU} / \mathrm{ml}$ (Male: 1.6-8.0). 8 A.M. testosterone was $70 \mathrm{ng} / \mathrm{dl}$ (Male: 300-1000ng/dl $)^{3,4}$. LH-releasing hormone stimulation test was planned but could not be done. Karyotyping confirmed 46 XY. Bone age corresponded to chronological age. All other investigations including thyroid profile, serum cortisol, prolactin level, and hearing test were within normal range. Thus, this patient was diagnosed as

\footnotetext{
${ }^{1}$ Institute of Child Health, Kolkata, India

*Correspondence: kakaliroy.nrs2007@gmail.com
}

(Received on 26 November 2015: Accepted after revision on 21 January 2016)

The authors declare that there are no conflicts of interest

Personal funding was used for the project.

Open Access Article published under the Creative Commons Attribution CC-BY cc) (†) License. hypogonadotrophic hypogonadism. With background history of anosmia since childhood, our diagnosis was Kallmann syndrome. For further evaluation we did MRI of brain, which revealed absent olfactory bulb and tract in anterior sections and also absence of olfactory sulcus (OS). The medial orbital gyrus (MOG) and gyrus rectus (GR) were fused. (Figures 1 and 2).

\section{Discussion}

Male patients usually present in the second decade with failure to start or fully complete puberty and have the additional symptoms of hypogonadism and almost invariably infertility. Females usually present with primary amenorrhoea. Pre-pubertal boys sometimes may present with microphallus and cryptorchidism ${ }^{5}$. Although anosmia is present since birth it is usually not apparent. They may also exhibit bimanual synkinesis i.e. simultaneous movement of both hands which is mainly seen in inherited $\mathrm{KS}^{6}$. Symptoms of associated congenital heart disease or neurologic manifestations may be present. Rarely patients may have one kidney and features of osteoporosis ${ }^{7}$.

Regarding inheritance, Kallmann syndrome may be sporadic or can be inherited as three modes, Xlinked, autosomal dominant and autosomal recessive. X-linked form is the most common and the responsible gene is KAL1 that encodes the protein anosmin which is directly responsible for the migration of gonadotrophin releasing hormone $(\mathrm{GnRH})$ neurons and the olfactory nerves from the olfactory system to the hypothalamus. Patients with $\mathrm{KS}$, therefore, suffer both reproductive and olfactory dysfunction. The next common inheritance is the autosomal dominant form due to a mutation of the KAL2 gene on chromosome 8.The third inherited form is autosomal recessive due to the mutation of the KAL3 gene. The exact location of the KAL3 gene has not yet been discovered ${ }^{8-11}$. 

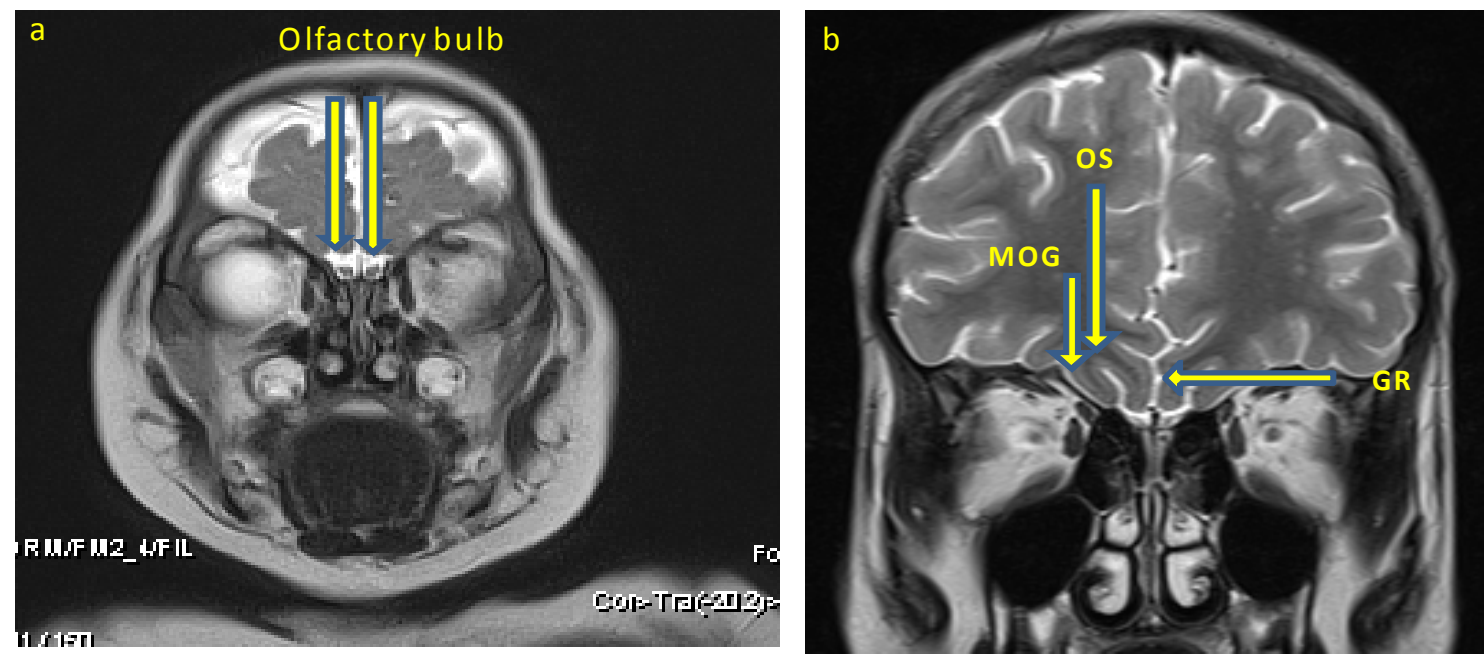

Figure 1: Cranial magnetic resonance imaging of the olfactory bulb region in a control man
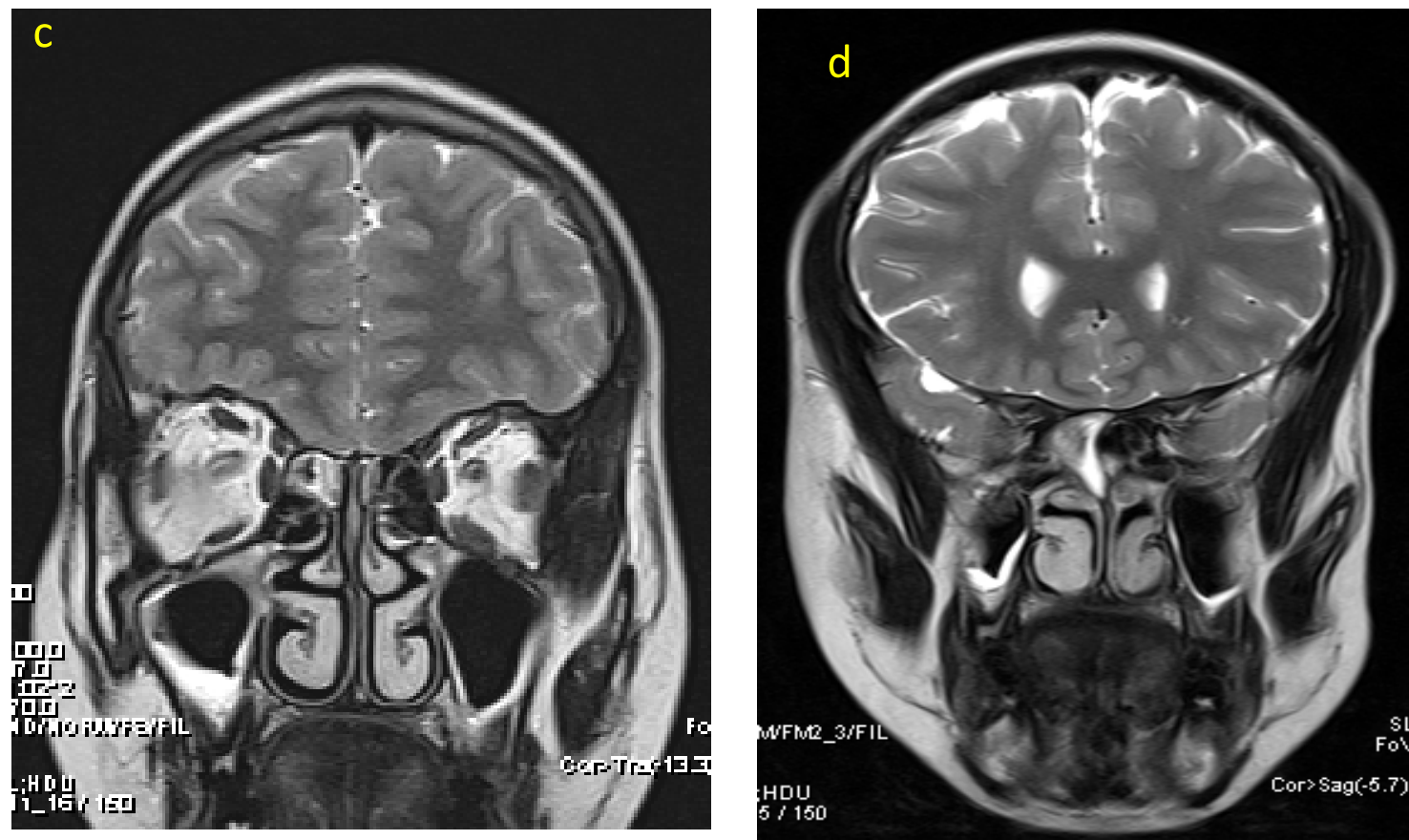

Figure 2: Cranial magnetic resonance imaging of the olfactory bulb region in Kallmann syndrome

Molecular pathogenesis says that there is impaired development of olfactory axon and the migration of GnRH neurons that fail to migrate from the medial olfactory placode into the forebrain. There is also failure of neuronal migration from the lateral olfactory placode to the forebrain resulting in aplasia or hypoplasia of the olfactory bulbs and tracts, which can be evaluated in MRI (Figure 2) $)^{12}$.

MRI of brain is an important tool. To look at the olfactory bulbs and tracts, study of more anterior and thin coronal sections on T2W, MR images are important. As KS is a neuronal migration disorder, associated abnormalities like fusion of gyrus rectus and medial orbital gyrus, shallow or absent orbital sulcus may be evident. MRI can also show a possible associated brain abnormalities ${ }^{13}$.

Medical treatment can reverse the problem of hypogonadism and the management aims for normal reproductive health. Replacement of the missing hormones is the main focus. For the male, testosterone can be given as Injection Slow-release skin patch or gels and for the female oestrogen and progesterone pills which help to develop secondary sexual characteristics. When fertility is required Pulsed gonadotrophin releasing hormone is administered, which has a complex schedule with variable success ${ }^{14,15}$. 


\section{References}

1. Dodé C, Hardelin JP. Kallmann syndrome. European Journal of Human Genetics 2009; 17: $139-46$.

http://dx.doi.org/10.1038/ejhg.2008.206

PMid: 18985070 PMCid: PMC2986064

2. Morgan MA, Jha P. Testes, radiopedia. Accessed on 24.06.2015. Available from: http://radiopaedia.org/articles/testes

3. Testcenter/BU OrderInfo.action accessed on 12.05.2015. Available from:

http://www.questdiagnostics.com/

4. Severson A, Barclay RS et al. Testosterone Levels by Age, healthline. March 23, 2015. Available from:

http://www.healthline.com/health/lowtestost erone/testosterone-levels-by-age

5. Tritos NA,et al. Kallmann Syndrome and Idiopathic hypogonadotropic hypogonadism Clinical Presentation, Medscape. Available from:

http://emedicine.medscape.com/article/

6. Kallmann's Syndrome Information. The pituitary foundation. Available from: http://kallmanns.org/node/95

7. Nishio H, Mizuno K, Moritoki Y, Kamisawa $\mathrm{H}$, Kojima Y, Mizuno H, et al. Clinical features and testicular morphology in patients with Kallmann syndrome. Urology 2012; 79(3): 684-6.

http://dx.doi.org/10.1016/j.urology.2011.10.

032

PMid: 22173178

8. Hardelin JP, Levilliers J, Blanchard S, Carel JC, Leutenegger M, Bertelletto JPP et al. Heterogeneity in the mutations responsible for X chromosome-linked Kallmann syndrome. Oxford Journals-Human Molecular Genetics 1993; 2(4):373-77. http://dx.doi.org/10.1093/hmg/2.4.373

9. Soderlund D, Canto P, Mendez JP: Identification of three novel mutations in the KAL1 gene in patients with Kallmann syndrome. Journal of Clinical Endocrinology and Metabolism 2002; 87:2589-92. http://dx.doi.org/10.1210/jcem.87.6.8611
10. Legouis R, Hardelin JP, Levilliers J, Claverie JM, Compain S, Wunderle V, Millasseau P, Le Paslier D, Cohen D, Caterina D: The candidate gene for the X-linked Kallmann syndrome encodes a protein related to adhesion molecules. Cell 1991; 67:423-33. http://dx.doi.org/10.1016/00928674(91)9019 3-3

11. Franco B, Guioli S, Pragliola A, Incerti B, Bardoni B, Tonlorenzi R, Carrozzo R, Maestrini E, Pieretti M, Taillon-Miller : A gene deleted in Kallmann's syndrome shares homology with neural cell adhesion and axonal path-finding molecules. Nature 1991; 353:529-36.

http://dx.doi.org/10.1038/353529a0

PMid: 1922361

12. Truwit CL, Barkovich AJ, Grumbach MM, Martini JJ. MR imaging of Kallmann syndrome, a genetic disorder of neuronal migration affecting the olfactory and genital systems. American Journal of Neuroradiology 1993; 14: 827-38. PMid: 8352153

13. Zaghouani H, Slim I, Zina NB, Mallat N, Tajouri H, Kraiem $\mathrm{C}$ et al. Kallmann syndrome: MRI findings. Indian Journal of Endocrinology and Metabolism 2013; 17: S142-S145. http://dx.doi.org/10.4103/22308210.119536 PMid: 24251137 PMCid: PMC3830283

14. Eisenbud E. Treatment of Kallmann Syndrome. The Journal of the American Medical Association 1976; 235(1):23-24. http://dx.doi.org/10.1001/jama.1976.032602 70013014

PMid: 1081605

15. Kousta E, White DM, Piazzi A, Loumaye E, Franks S. Successful induction of ovulation and completed pregnancy using recombinant human luteinizing hormone and follicle stimulating hormone in a woman with Kallmann's syndrome. Oxford JournalsHuman Reproduction 1995; 11(1): 70-71. http://dx.doi.org/10.1093/oxfordjournals.hu mrep.a019039 